Brazilian Journal
of Chemical
Engineering

ISSN 0104-6632

Printed in Brazil

www.abeq.org.br/bjche

Vol. 28, No. 03, pp. 381 - 391, July - September, 2011

\title{
CATALYTIC PROPERTIES OF IMMOBILIZED TANNASE PRODUCED FROM Aspergillus aculeatus COMPARED WITH THE FREE ENZYME
}

\author{
A. B. EL-Tanash", A. A. Sherief and A. Nour \\ Faculty of Science, Botany Department, Mansoura University, Mansoura, Egypt. \\ E-mail: arafattanash@yahoo.com; dshrif2004@yahoo.com \\ (Submitted: January 6, 2011 ; Revised: April 11, 2011 ; Accepted: April 23, 2011)
}

\begin{abstract}
Aspergillus aculeatus tannase was immobilized on several carriers by entrapment and covalent binding with cross-linking. Tannase immobilized on gelatin with cross-linking agent showed the highest activity and immobilization yield. The optimum $\mathrm{pH}$ of the immobilized enzyme was shifted to a more acidic range compared with the free enzyme (from $\mathrm{pH} 5.5$ to $\mathrm{pH} 5.0$ ). The optimum temperature of the reaction was determined to be $50^{\circ} \mathrm{C}$ for the free enzyme and $60^{\circ} \mathrm{C}$ for the immobilized form. The thermal stability, as well as stability over a wide range of $\mathrm{pH}$, was significantly improved by the immobilization process. The calculated $\mathrm{K}_{\mathrm{m}}$ of the immobilized tannase $\left(11.8 \mathrm{mg} \mathrm{ml}^{-1}\right)$ is higher than that of the free tannase $\left(6.5 \mathrm{mg} \mathrm{ml}^{-1}\right)$, while $\mathrm{V}_{\max }$ of the immobilized enzyme $\left.(0.32 \mathrm{U} \text { ( } \mu \mathrm{g} \text { protein })^{-1}\right)$ is lower than that of the free tannase $\left(2.7 \mathrm{U}(\mu \mathrm{g} \text { protein })^{-1}\right)$. The immobilized enzyme was able to retain $84 \%$ of the initial catalytic activity after 5.0 cycles.

Keywords: Tannase; Enzyme immobilization; SSF, Green tea (Camellia sinensis L.).
\end{abstract}

\section{INTRODUCTION}

The hydrolysis of tannic acid by tannase results in the liberation of glucose, gallic acid and other galloyl esters of glucose (Van de Lagemaat and Pyle, 2006). Bacteria (Kumar et al., 2010), yeasts (Zhong et al., 2004) and filamentous fungi (Battestin and Macedo, 2007; Hamdy, 2008) are able to degrade hydrolysable tannins and produce tannase. However, Aspergillus and Penicillum are the best tannase producers during submerged $(\mathrm{SmF})$ and solid state fermentation (Aguilar et al., 2007; Kumar et al., 2007). These fungi tolerate the higher concentrations of tannic acid and other tannery effluents without deleterious effects on either growth or enzyme production (Belmare et al., 2004). Further studies reported that tannase is mainly intracellular at the beginning, but is then secreted to the culture medium due to the proteolytic activities in the culture system (Aguilar et al., 2007).

Depend on the catalytic efficiency of gallic acid production, tannase has wide industrial applications. Gallic acid is used in pharmaceutical industry for synthesis of antibacterial and anti-malarial drugs (Trimethoprim) (Bajpai and Patil, 1997; Yu et al., 2004). In the food industry, gallic acid is also used as the substrate for the chemical synthesis of food preservatives antioxidants such as pyrogallol and gallates (Belmare et al., 2004; Vaquero et al., 2004). These antioxidants are also employed in cosmetics, hair products, adhesives and lubricant industry ( $\mathrm{Yu}$ and $\mathrm{Li}, 2006$ ). The applications of tannase in the food industry also include the removal of the undesirable effects of tannins as in instant tea (Boadi and Neufeld, 2001). Treatment of tea with tannase inhibits the carcinogenic and mutagenic effects of

*To whom correspondence should be addressed 
$\mathrm{N}$-nitrosamines $\mathrm{Lu}$ and Chen, 2007). Furthermore, improvement of the color and organoleptic properties of tea occurred when it was treated with tannase $(\mathrm{Lu}$ et al., 2009). Tannase is also used in clarification to remove the unwanted bitterness in many fruits juices, lowering haze without deteriorating juice quality (Rout and Banerjee, 2006; Srivastava and Kar, 2010). In animal feed, tannase is used to reduce the anti-nutritional effects of tannins and improve animal digestibility (Graminha et al., 2008; Murugan and Al-Sohaibani, 2010).

There are several methods for tannase immobilization. Entrapment inside a semi-permeable membrane capsule using sodium alginate is very common and cost effective and shows good performance in industrial applications. As anticipated, Abdel-Naby et al. (1999) observed a higher activity of tannase when cross-linked to the surface of chitosan beads than when entrapped in polyacrylamide or calcium alginate. Tannase could be bioaffinity immobilized on concanavalin ASepharose CL-4B beads (Sharma et al., 2002) and microencapsulated in a coacervate calcium alginate membrane (Yu et al., 2004), with higher conversion of methyl gallate/tannic acid into gallic acid than with the free enzyme.

To date, there are no publications focusing on immobilized Aspergillus aculeatus tannase. However, other immobilized tannases have been used for tannin degradation in tea extracts for instant tea manufacture and tea cream removal. This application has many advantages, such as avoiding heating of the tea, improved flavor and reduced costs (Boadi and Neufeld, 2002). For industrial applications, immobilized enzymes offer several advantages relative to the soluble form, including; repeated use of the enzyme, convenience of product separation, improvement of enzyme stability, and continuous operation in packed-bed reactors. Furthermore, other tannases could be immobilized for gallic acid production through bioconversion of tannin-rich agro/forest-residues (Hota et al., 2007; Cruz-Aldaco et al., 2009). Despite of its importance, more work on different forms of tannase is needed to increase its application and clearly established its optimum temperature, $\mathrm{pH}$ conditions, thermal stability and operational stability. This research is an extension of a study on tannase production from some Aspergillus species under solid state fermentation using commercial green tea (Camellia sinensis L) as solid substrate (Sherief et al., 2011).

The objective of this paper was to immobilize tannase to improve its thermal, $\mathrm{pH}$ and operational stabilities compared with the free enzyme.

\section{MATERIALS AND METHODS}

\section{Microorganism and Culture Maintenance}

The fungal strain used in the present study was isolated from a tannery soil sample and identified as Aspergillus aculeatus by the Regional Center for Mycology and Biotechnology (RCMB), Al-Azhar University, Egypt. The strain was sub-cultured on modified Czapek's agar media containing 0.5\% tannic acid as sole carbon source at $30^{\circ} \mathrm{C}$ for 7.0 days and maintained at $4^{\circ} \mathrm{C}$. Induced slants of Aspergillus aculeatus were mixed with $10 \mathrm{~mL}$ of basal medium to prepare the spore suspension. The spore count in the suspension was $2.0 \times 10^{7}$ spore $\mathrm{mL}^{-1}$.

\section{Raw Materials for Solid State Fermentation}

Commercial green tea (Camellia sinensis L.) was collected from the local market in Al-Mansoura, Egypt, dried at $70^{\circ} \mathrm{C}$ and used as tannin substrate under solid state fermentation.

\section{Mode of Fermentation and Tannase Extraction}

Tannase production by Aspergillus aculeatus was performed through batch solid state fermentation using green tea as the source of tannins (tannic acid). One gram of solid substrate was transferred to a 250 $\mathrm{mL}$ Erlenmeyer flask and mixed with $3.0 \mathrm{~mL}$ of basal medium $\left(0.3 \%\right.$ peptone; $0.1 \% \mathrm{CaCl}_{2}-2 \mathrm{H}_{2} \mathrm{O}$, $0.1 \% \mathrm{KH}_{2} \mathrm{PO}_{4}$ and $0.05 \% \mathrm{MgSO}_{4}-7 \mathrm{H}_{2} \mathrm{O}$ ); then the mixture was autoclaved at $121^{\circ} \mathrm{C}$ at $15 \mathrm{lbs}$ for 20 min. After cooling, the medium was inoculated under aseptic conditions by $1.0 \mathrm{~mL}$ of spore suspension $\left(2.0 \times 10^{7}\right.$ spores $)$ and incubated at $30^{\circ} \mathrm{C}$ under static conditions. The final moisture content was $80 \%$. After 4.0 days of incubation, the fermented substrates were mixed by adding $30 \mathrm{~mL}$ of $0.1 \mathrm{M}$ acetate buffer $(\mathrm{pH}$ 5.5) to the fermented medium. The flasks were then kept on a rotating shaker for $1.0 \mathrm{~h}$ at $10^{\circ} \mathrm{C}$ and centrifuged at $5000 \mathrm{rpm}$ for $10 \mathrm{~min}$ to remove all fungal cells and residue of the substrate. The clarified extract was collected and stored in a freezer $\left(-20^{\circ} \mathrm{C}\right)$ until it was used as crude tannase.

\section{Assay of Tannase Activity}

Tannase activity was estimated by detection of the gallic acid liberated from the used substrate (tannic acid) through two steps. The first step was the precipitation of unhydrolyzed tannins with quinine $\mathrm{HCl}$ solution, as reported by Nishira and 
Mugibayashi (1958). The second step was to estimate the released gallic acid as reported by Deschamps et al. (1983). One unit of tannase activity (U) was defined as the amount of enzyme that liberates $1.0 \mu \mathrm{mol}$ gallic acid per min under assay conditions.

\section{Protein Determination}

Soluble protein was determined according to Bradford (1976) by measuring the optical density of the colour developed at $595 \mathrm{~nm}$ using a Spectro UV-VIS RS spectrophotometer (Labomed Inc. U.S.A). The $\mu \mathrm{g}$ of protein was estimated using bovine serum albumin (BSA) as standard.

\section{Immobilization Methods of Tannase}

\section{Covalent Binding with Cross-Linking}

Chitin $(1.0 \mathrm{~g})$ was shaken with $10 \mathrm{ml}$ of $2.5 \%$ glutaraldehyde. Chitin was then collected by filtration using a sintered glass funnel and washed with distilled water to remove the excess glutaraldehyde. The wet chitin was mixed with 4.0 $\mathrm{ml}$ of the enzyme solution $(300 \mathrm{U}$; A. aculeatus tannase) for $1.0 \mathrm{~h}$ at room temperature $\left(23-25^{\circ} \mathrm{C}\right)$. The unbound tannase were removed by washing with $0.1 \mathrm{M}$ acetate buffer $\mathrm{pH} 5.5$ (Abdel-Naby et al., 1999).

One gram of gelatin/BSA was dissolved by heating $\left(\right.$ at $\left.50^{\circ} \mathrm{C}\right)$ and treated with $0.7 \mathrm{~mL}(50 \% \mathrm{v} / \mathrm{v})$ of glutaraldehyde. The final concentration of gelatin was kept at $10 \%(\mathrm{w} / \mathrm{v})$ and cooled to room temperature. Then $4.0 \mathrm{ml} \mathrm{A}$. aculeatus tannase solution (containing $300 \mathrm{U}$ ) was added to the mixture and incubated overnight at $4.0^{\circ} \mathrm{C}$. The resulting gel was washed and then cut into small cubes $\left(0.2 \mathrm{~cm}^{3}\right)$ (Ghosh and Nanda, 1993).

\section{Entrapment in Ca-Alginate}

According to Abdel-Naby et al. (1999), A. aculeatus tannase solution $(4.0 \mathrm{~mL}$, containing $300 \mathrm{U})$ was mixed with different concentrations of sodium alginate (Pharmacia chemicals) to final concentrations of $3.0,5.0$, and $7.0 \%$. The entrapment was carried out by dropping alginate solution in $0.1 \mathrm{M} \mathrm{CaCl}_{2}$ solution. The resulting beads were collected, washed with acetate buffer $(0.1 \mathrm{M}$; $\mathrm{pH}$ 5.5) and kept in the same buffer at room temperature for 2.0 hours to remove the unbound enzyme.

\section{Properties of the Free and Immobilized Tannase}

\section{Optimum pH}

The optimum $\mathrm{pH}$ for free and immobilized tannase was determined by incubating each enzyme at different $\mathrm{pH}$ values $(0.1 \mathrm{M}$ acetate buffer was used for the range from $\mathrm{pH} 3.5$ to 5.5 and $0.1 \mathrm{M}$ phosphate buffer for $\mathrm{pH} 6.0$ to 8.0 ) at $45^{\circ} \mathrm{C}$ for 20 min using $2.0 \%$ tannic acid as substrate with different controls. Tannase activity was then assayed as described above.

\section{Optimum Temperature}

The effect of temperature was studied by incubating both soluble and immobilized tannase in their respective optimum $\mathrm{pH}$ at different temperatures (ranging from 25 to $70^{\circ} \mathrm{C}$ ) with different controls for 20 min using $2.0 \%$ tannic acid as substrate.

\section{Activation Energy $\left(E_{a}\right)$}

The activation Energy was determined from the slope of a linear plot of the log of the enzyme activity (v) versus $1 / \mathrm{T}$, according to the Arrhenius law:

$$
\log (\mathrm{v})=\mathrm{Cte}-\mathrm{E}_{\mathrm{a}} /(\mathrm{RT})
$$

The enzyme activity $(v)$ was expressed in $U(\mu \mathrm{g}$ protein $)^{-1}$, the temperature $(\mathrm{T})$ in Kelvin $(\mathrm{K})$, the gas constant $\left(\mathrm{R}=1.987 \mathrm{cal} \mathrm{K}^{-1} \mathrm{~mol}^{-1}\right)$ and the activation energy $\left(E_{a}\right)$ in kcal mol${ }^{-1}$.

\section{pH Stability}

The $\mathrm{pH}$ stability of the free and immobilized enzyme was examined after pre-incubating enzyme samples at $25^{\circ} \mathrm{C}$ for $30 \mathrm{~min}$ at different $\mathrm{pH}$ values $(0.1 \mathrm{M}$ acetate buffer was used for the range from $\mathrm{pH} 3.5$ to 5.5 and $0.1 \mathrm{M}$ phosphate buffer for $\mathrm{pH} 6.0$ to 8.0 ), followed by adjusting the $\mathrm{pH}$ to the value of the standard assay system. The residual activity was assayed under the standard conditions for free $\left(\mathrm{pH} 5.5\right.$ and $\left.50^{\circ} \mathrm{C}\right)$ and immobilized tannase ( $\mathrm{pH} 5.0$ and $\left.60^{\circ} \mathrm{C}\right)$.

\section{Thermal Stability}

The enzyme samples were incubated in $0.1 \mathrm{M}$ acetate buffer at designated temperatures of 60,70 and $80^{\circ} \mathrm{C}$ for times ranging from 5.0 to $90 \mathrm{~min}$. The residual activity was assayed under the standard conditions for free $\left(\mathrm{pH} \quad 5.5\right.$ and $\left.50^{\circ} \mathrm{C}\right)$ and immobilized tannase $\left(\mathrm{pH} 5.0\right.$ and $\left.60^{\circ} \mathrm{C}\right)$. 


\section{Determination of the Half-Life $\left(t_{1 / 2}\right)$}

The half-life of the enzyme activity $\left(t_{1 / 2}\right)$, which corresponds to the time necessary for the residual enzyme activity to decrease to $50 \%$ of its initial value, can be calculated from the equation:

$\mathrm{t}_{1 / 2}=0.693 / \mathrm{K}_{\mathrm{d}}$

\section{Determination of the Deactivation Energy $\left(\mathbf{E}_{\mathrm{d}}\right)$}

The deactivation energies of free and immobilized tannase were determined by plotting the activity data [log of the ratio of Ar (residual activity) $/ \mathrm{A}_{0}$ (initial activity)] as a function of time to obtain the deactivation rate constant $\left(\mathrm{K}_{\mathrm{d}}\right)$ at each temperature. From Arrhenius equation:

$\mathrm{K}_{\mathrm{d}}=\mathrm{K}_{\mathrm{do}} \exp \left(-\mathrm{E}_{\mathrm{d}} / \mathrm{RT}\right)$

plotting the $\log$ of $\mathrm{K}_{\mathrm{d}}$ as a function of the inverse of the absolute temperature, the energy of deactivation $\left(\mathrm{E}_{\mathrm{d}}\right)$ is obtained as the product of the slope of the resultant straight line times $\mathrm{R}$, the universal gas constant.

\section{Kinetic Values $\left(K_{m}\right.$ and $\left.V_{\text {max }}\right)$}

Following Abdel-Naby et al. (1999) different concentrations of pure tannic acid (Sigma) (2.0-50 $\mathrm{mg} \mathrm{mL}^{-1}$ ) were prepared for tannase assay. The enzyme activity was determined after $30 \mathrm{~min}$ incubation at $50^{\circ} \mathrm{C}$ for free enzyme and at $60^{\circ} \mathrm{C}$ for immobilized tannase. The kinetic values of the enzyme $\left(\mathrm{K}_{\mathrm{m}}\right.$, and $\left.\mathrm{V}_{\max }\right)$ were investigated through Hanes-Woolf plots of the different substrate concentrations [S] against [S/V] using Graph-Pad Prism 5 software.

\section{Effect of Different Metal Ions}

This was determined by pre-incubating the enzyme solution or the immobilized form with the test substance $(1.0 \%, \mathrm{w} / \mathrm{v})$ for $30 \mathrm{~min}$ at room temperature. Then, the residual activity was assayed at the optimum conditions.

\section{Operational Stability of the Immobilized Tannase}

$1.0 \mathrm{~g}$ of wetted gelatin-immobilized $A$. aculeatus tannase was incubated with $5.0 \mathrm{~mL}$ of $2.0 \%(\mathrm{w} / \mathrm{v})$ tannic acid in acetate buffer $(0.1 \mathrm{M}, \mathrm{pH} 5.0)$ at $60^{\circ} \mathrm{C}$ for $30 \mathrm{~min}$. At the end of the reaction, the immobilized enzyme was collected by filtration, washed with distilled water, and re-suspended in $5.0 \mathrm{~mL}$ of freshly prepared substrate to start a new run. The supernatant fluid was assayed for gallic acid.

\section{Reproducibility}

All the experiments were repeated at least four times and the results were reproducible. The data points represent the mean values within $\pm 5.0 \%$ of the individual values.

\section{RESULTS AND DISCUSSION}

\section{Immobilization Process}

Tannase from $A$. aculeatus was immobilized by two methods, including: 1) covalent binding with cross-linker on chitin, bovine serum albumin (BSA) and gelatin; and 2) entrapment in Ca-alginate (Table 1). The immobilized enzyme prepared by covalent binding with cross-linker to gelatin had the highest specific activity $\left(0.19 \mathrm{U}(\mu g \text { protein })^{-1}\right)$ and the highest immobilization yield $(28.4 \%)$ and it was therefore used in the succeeding part of this work. In this connection, Cao (2005) suggested that immobilization by covalent binding using a crosslinking agent (glutaraldehyde) probably increases the local surface area, which contributes to minimizing the steric effect around the active site of the immobilized enzyme. In addition, these results are similar to those reported by Abel-Naby et al. (1999).

Table 1: Immobilization of $\boldsymbol{A}$. aculeatus tannase on different carriers

\begin{tabular}{|c|c|c|c|c|c|c|}
\hline \multirow[b]{2}{*}{$\begin{array}{l}\text { Immobilization } \\
\text { method }\end{array}$} & \multirow[b]{2}{*}{ Carriers } & \multicolumn{3}{|c|}{ Enzyme units } & \multirow[b]{2}{*}{$\begin{array}{l}\text { Immobilization } \\
\text { Yield I/(A-B)\% }\end{array}$} & \multirow[b]{2}{*}{$\begin{array}{l}\text { Specific activity } \\
\mathbf{U}(\mu \mathrm{g} \text { protein })^{-1}\end{array}$} \\
\hline & & $\begin{array}{l}\text { Add } \\
\text { (A) }\end{array}$ & $\begin{array}{l}\text { Unbound } \\
\text { (B) }\end{array}$ & $\begin{array}{c}\text { Immobilized } \\
\text { (I) }\end{array}$ & & \\
\hline \multirow{3}{*}{ Covalent bonding } & Chitin & 300 & 90 & 50 & 23.8 & 0.176 \\
\hline & Gelatin & 300 & 40 & 74 & 28.4 & 0.190 \\
\hline & BSA & 300 & 50 & 63 & 25.2 & 0.182 \\
\hline \multirow{3}{*}{ Entrapment } & Alginate (3\%) & 300 & 70 & 40 & 17.4 & 0.152 \\
\hline & Alginate $(5 \%)$ & 300 & 60 & 30 & 12.5 & 0.140 \\
\hline & Alginate $(7 \%)$ & 300 & 50 & 21 & 08.4 & 0.132 \\
\hline
\end{tabular}


The immobilization yields of the immobilized enzyme by entrapment on 3.0, 5.0, and $7.0 \%$ Ca-alginate were $17.4,12.5$ and $8.4 \%$, respectively. This lower immobilization efficiency with entrapment may be due to enzyme leakage, as explained by Cao (2005). There are two counteracting factors affecting the efficiency of the immobilization by entrapment, the diffusion efficiency and enzyme leak out. Higher concentrations of alginate reduced the pore size of beads and, consequently, reduced leakage of enzyme. However, the diffusion efficiency of the substrate and internal transport was reduced. A lower percentage of alginate increased the pore size, which leads to increased leakage of enzyme, but reduced the limitations on substrate diffusion. Similar observations were previously reported for other immobilized tannases (Yu et al., 2004).

The specific activity exhibited by free tannase was $2.6 \mathrm{U}$ ( $\mu \mathrm{g}$ protein $)^{-1}$. However the specific activity of immobilized tannase on gelatin was $0.19 \mathrm{U}$ $(\mu \mathrm{g} \text { protein })^{-1}$. This drop in the specific activity after immobilization may be due to diffusion limitation (i.e., resistance to diffusion of the substrate into the immobilization matrix and resistance to diffusion out of the products), as reflected by the lower apparent activation energy for immobilized tannase (7.6 kcal mole vs. $9.8 \mathrm{kcal} \mathrm{mole} \mathrm{e}^{-1}$, see below). Lower activation energy for the immobilized enzyme has been reported to be an indication of diffusional limitations (Kitano et al., 1982). On the other hand, Gottschalk and Jaenicke (1991) reported that the immobilization of the enzyme by covalent binding could lead to a decrease in the flexibility of the enzyme molecule, which is commonly reflected by a decrease in catalytic activity. A decrease in specific activity after tannase immobilization has been previously reported (Abdel-Nabey et al., 1999).

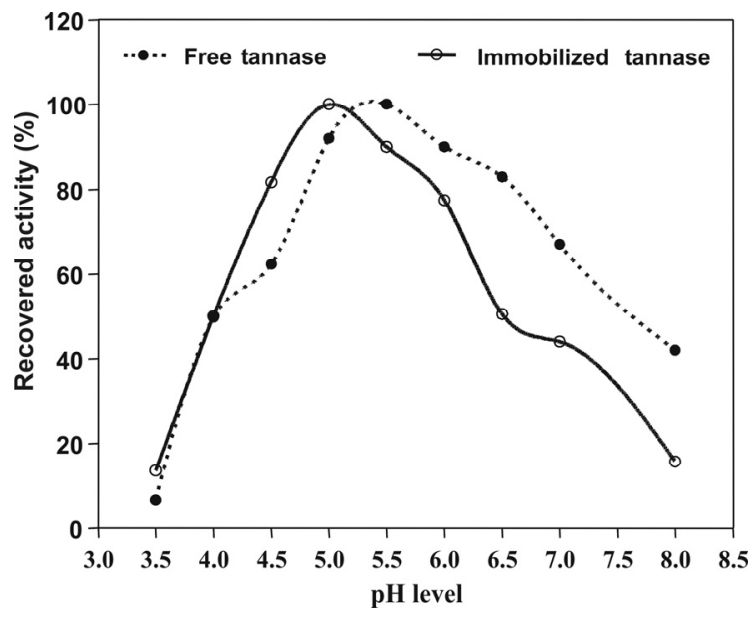

Figure 1: Effect of different $\mathrm{pH}$ levels on free and immobilized $A$. aculeatus tannase

\section{Optimum pH}

The optimum $\mathrm{pH}$ of immobilized tannase was shifted to a more acidic value than free tannase, reaching the maximal activity at $\mathrm{pH} 5.0$ as compared to $\mathrm{pH} 5.5$ as the optimum for free tannase (Figure 1). This may be attributed to an ionic change around the enzyme active site as result of the immobilization process (Krajewska et al., 1990). The shift of $\mathrm{pH}$ optima to more acidic $\mathrm{pH}$ values has been previously reported for other immobilized tannases (Abel-Naby et al., 1999, Srivastava and Kar, 2010). In contrast, the optimal $\mathrm{pH}$ of the $A$. niger tannase entrapped in Ca-alginate was shifted to a more alkaline range (Yu et al., 2004). Furthermore, both immobilized and free Aspergillus niger tannase have the same optimum pH (Sharma et al., 2008).

\section{pH Stability}

The profile of $\mathrm{pH}$ stability (Figure 2) showed that immobilized tannase was more stable in a wider range of $\mathrm{pH}(4.5-8.0)$ compared with the free enzyme (5.0- 6.0), where it retained $80 \%$ residual activity. This result means that immobilized tannase would be more resistant to $\mathrm{pH}$ changes and could be used industrially. This effect may have been caused by the micro-environmental $\mathrm{pH}$ of the gelatin matrix. At high $\mathrm{H}^{+}$concentrations, the amino groups of gelatin would be protonated, thereby attracting hydroxide ions, which would maintain a higher microenvironmental $\mathrm{pH}$ than in the bulk solution and thus stabilize the immobilized enzyme (Cao, 2005). These results are in agreement with those obtained for other immobilized tannases (Abdel-Naby et al., 1999; Yu et al., 2004).

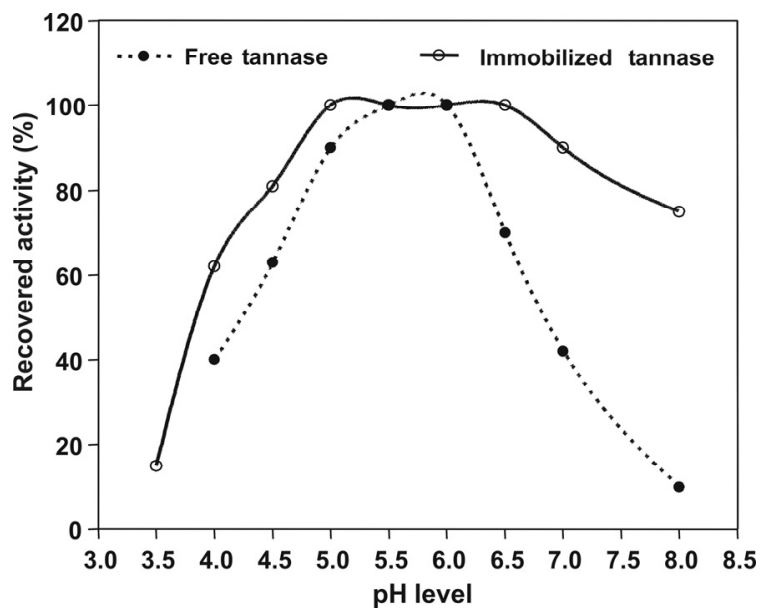

Figure 2: pH stability of free and immobilized $A$. aculeatus tannase 


\section{Optimum Temperature}

The effect of temperature on the activity of the immobilized and free tannase (Figure 3) shows that the optimum temperature is shifted from $50^{\circ} \mathrm{C}$ for free tannase to $60^{\circ} \mathrm{C}$ for immobilized tannase. This increase of the optimum temperature is probably a consequence of enhanced thermal stability. The shift of optimum temperature to higher values after the immobilization of tannase was previously reported by Sharma et al. (2008), Su et al. (2010) and Srivastava and Kar (2010).

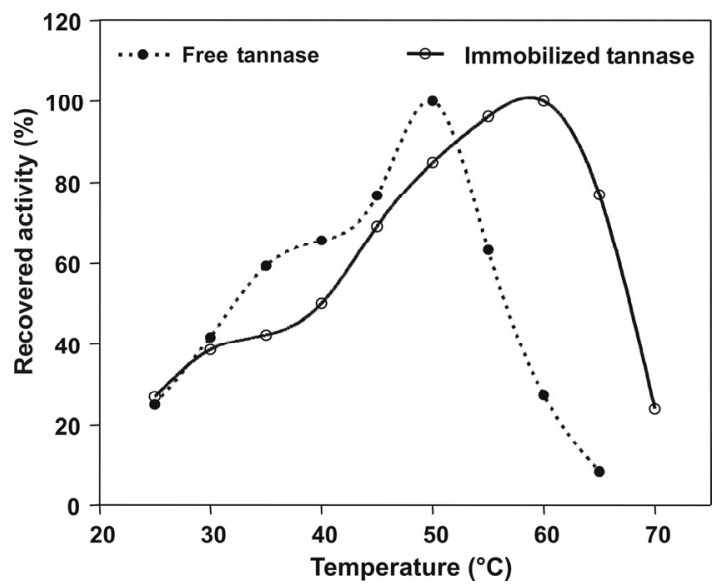

Figure 3: Effect of different temperatures on free and immobilized $A$. aculeatus tannase

The temperature data are replotted in the form of Arrhenius plots (Figure 4). The plots of both free and immobilized tannase were linear and the activation energy of immobilized tannase was lower (7.6 kcal mole $\mathrm{k}^{-1}$ ) than the activation energy of free enzyme $\left(9.8 \mathrm{kcal} \mathrm{mole}^{-1}\right)$. These results are similar to those reported for immobilized and free $A$. oryzae tannase (Abdel-Naby et al., 1999). This decrease in the activation energy may be due to the diffusion limitations (Yu et al., 2007).

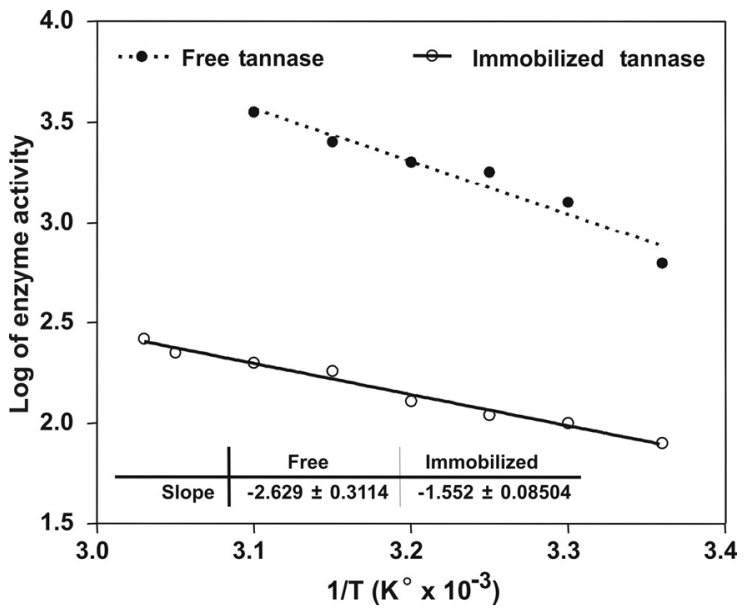

Figure 4: Arrhenius plots for the activation energy of free and immobilized $A$. aculeatus tannase

\section{Thermal Stability}

The results in Figure 5 indicate that the immobilization process significantly improves the thermal stability of immobilized tannase relative to free enzyme. For example, the immobilized tannase retained $83 \%$ of its original activity after heating for $90 \mathrm{~min}$ at $60^{\circ} \mathrm{C}$, while $76.2 \%$ of the activity was retained by the free enzyme after the same treatment. In addition, the calculated half-lives (Table 2) of the immobilized enzyme at 60,70 and $80^{\circ} \mathrm{C}$ were $312,47.4$, and $27.5 \mathrm{~min}$, respectively, whereas in the same conditions the free enzyme was less stable (half-lives of 195.9, 32.4, and $17.5 \mathrm{~min}$ respectively). Furthermore, the deactivation rate constant of the immobilized $A$. aculeatus tannase at $80^{\circ} \mathrm{C}$ was $2.51 \times 10^{-2} \mathrm{~min}$, which is lower than that of the free enzyme $\left(3.94 \times 10^{-2} \mathrm{~min}\right)$. The Arrhenius plot of deactivation energy (Figure 6) indicates that immobilization process is increase the thermal stability to tannase. The calculated value of deactivation energy (Table 2$)$ for free tannase $\left(45.8 \mathrm{kcal} \mathrm{mol}^{-1}\right)$ is lower than its value of immobilized tannase $\left(57.3 \mathrm{kcal} \mathrm{mol}^{-1}\right)$.

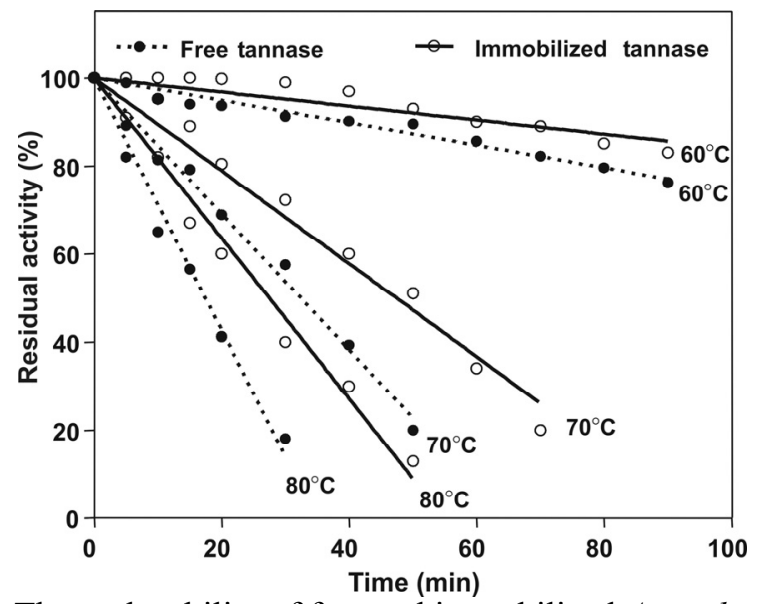

Figure 5: Thermal stability of free and immobilized A. aculeatus tannase 
Table 2: Comparison between the thermal stabilities of free and immobilized tannase

\begin{tabular}{|c|c|c|}
\hline & Free tannase & Immobilized tannase \\
\hline Optimum $\mathrm{pH}$ & 5.5 & 5.0 \\
Optimum temperature & $50^{\circ} \mathrm{C}$ & $60^{\circ} \mathrm{C}$ \\
Activation energy $\left(\mathrm{E}_{\mathrm{a}} ; \mathrm{kcal} \mathrm{mole}{ }^{-1}\right)$ & 9.8 & 7.6 \\
\hline \multicolumn{2}{|c|}{ Half life time (min) } & 312.3 \\
\hline $60^{\circ} \mathrm{C}$ & 195.9 & 47.4 \\
$70^{\circ} \mathrm{C}$ & 32.4 & 27.5 \\
$80^{\circ} \mathrm{C}$ & 17.5 & $0.22 \times 10^{-2}$ \\
\hline & Deactivation rate constant $\left.\mathbf{K}_{\boldsymbol{d}} \mathbf{( m i n}^{-\mathbf{1}}\right)$ & $1.46 \times 10^{-2}$ \\
\hline $70^{\circ} \mathrm{C}$ & $0.35 \times 10^{-2}$ & $2.51 \times 10^{-2}$ \\
$80^{\circ} \mathrm{C}$ & $2.13 \times 10^{-2}$ & 57.3 \\
$\mathrm{~K}_{\mathrm{m}}\left(\mathrm{mg} \mathrm{m} \mathbf{l}^{-1}\right)$ & $3.94 \times 10^{-2}$ & 11.8 \\
$\mathrm{~V}_{\text {max }}$ & 45.8 & 0.32 \\
\hline
\end{tabular}

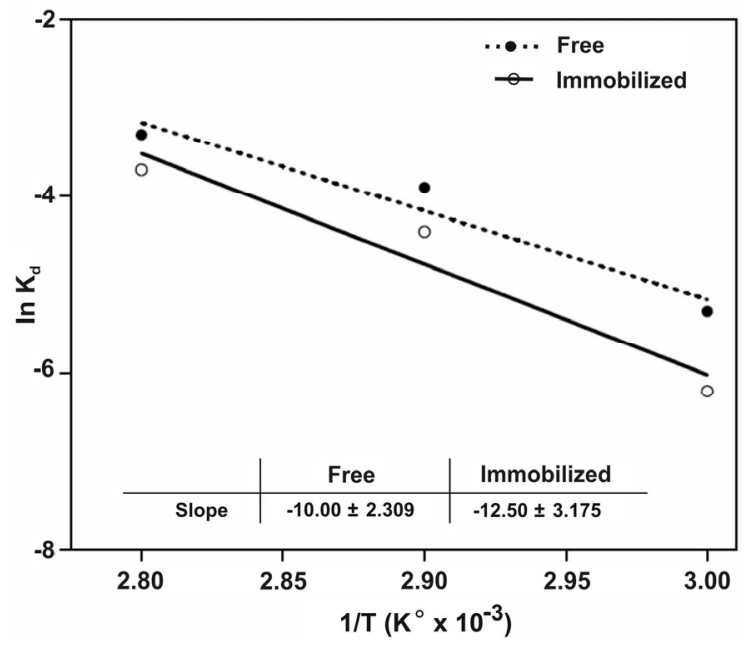

Figure 6: Arrhenius plots for the deactivation energy of free and immobilized A. aculeatus tannase

\section{Kinetic Values $\left(K_{m}\right.$ and $\left.V_{\max }\right)$}

A plot of the activity of free and immobilized tannase on pure tannic acid is illustrated in Figure 7 (a) and (b), showing that $\mathrm{K}_{\mathrm{m}}$ of the immobilized tannase $\left(11.8 \mathrm{mg} \mathrm{ml}^{-1}\right)$ is higher than the value of free tannase $\left(6.5 \mathrm{mg} \mathrm{ml}^{-1}\right)$, while $\mathrm{V}_{\max }$ of the immobilized enzyme $\left(0.32 \mathrm{U}(\mu \mathrm{g} \text { protein })^{-1}\right)$ is lower than that of free tannase $\left(2.7 \mathrm{U}(\mu \mathrm{g} \text { protein })^{-1}\right)$.

This increase of the $K_{m}$ value after the immobilization may be partially due to mass transfer resistance to diffusion into the immobilization matrices and/or to low substrate accessibility to the enzyme active site. On the other hand, fixation of the enzyme on the immobilization matrix could lead to a decrease in the flexibility of the enzyme molecule, which is commonly reflected by a decrease in the catalytic activity (Cao, 2005). Consequently, the maximum rate of the reaction catalyzed by the immobilized enzymes was lower than that of the free enzyme. Several researchers reported an increase of $\mathrm{K}_{\mathrm{m}}$ and decrease of $\mathrm{V}_{\max }$ for tannase due to immobilization (Abdel-Naby et al., 1999; Yu et al., 2004, 2007; Su, et al., 2010).

\section{Effect of Different Metal Ions}

In this experiment, free and immobilized enzymes were incubated with different metal ions in solution at room temperature for 30 minutes. Then the residual activity was measured at optimum conditions. The results in Table 3 show that $\mathrm{Ca}^{2+}$ ion is significantly activating for both free and immobilized tannase (residual activity is $118 \%$ and 
$112.4 \%$ for immobilized and free tannase, respectively), while $\mathrm{Mg}^{2+}$ ion is only activating for the immobilized enzyme (residual activity is $107 \%$ ). Gelatin as a carrier appears to protect tannase against the inhibitory effect of other metal ions; hence, it was generally observed that the inhibitory effects of the ions were less pronounced in immobilized tannase compared with the free enzyme. This protection may be due to the following: 1) structureal changes in the enzyme molecule introduced by the immobilization procedure, lower the accessibility of inhibiting ions to the active site of the enzyme; and 2) the chelating effect of gelatin, which is known to be a very powerful chelating agent, especially

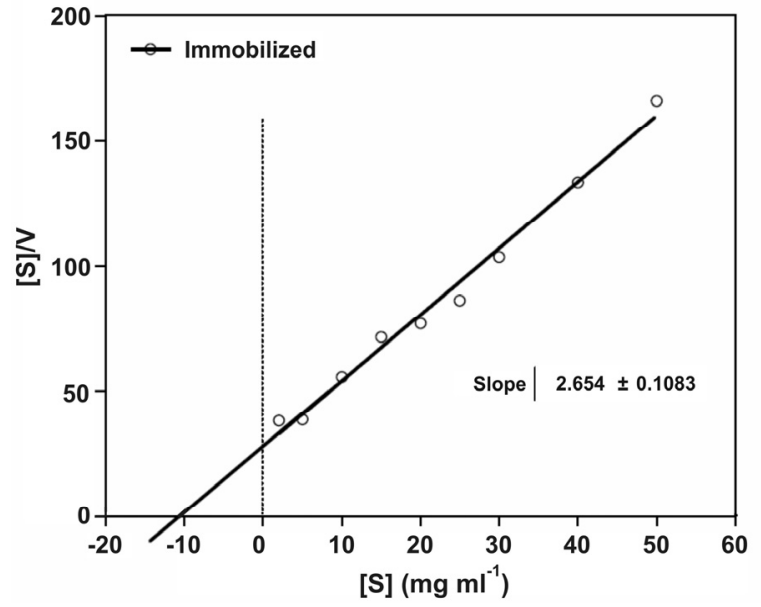

(a) when cross-linked with glutaraldehyde forming glutaraldehyde- cross-linked- gelatin particles (Kennedy, and Kalogerakis, 1980).

Enzyme inactivation by heavy metals, including mercury $\left(\mathrm{Hg}^{2+}\right)$, proceeds by the reduction of the thiol group in cysteine residues, with the formation of mercaptides, or the reduction of disulfide bridges, leading to S-Hg-S bonds (Vallee and Ulmer, 1972). These results are in agreement with those obtained for immobilized tannase by Abdel-Naby et al. (1999). Furthermore, $\mathrm{Su}$ et al. (2010) reported that $\mathrm{Fe}^{2+}$ and $\mathrm{Mn}^{2+}$ could enhance the activity of immobilized tannase when used for tannin degradation in extracts of green tea, black tea and oolong tea.

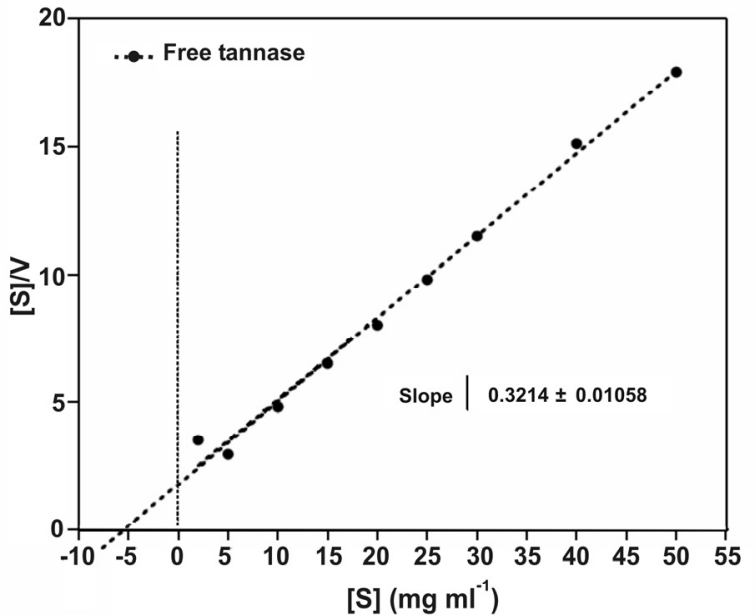

(b)

Figure 7: Hanes-Woolf plots of immobilized and free A. aculeatus tannase acting on pure tannic acid

Table 3: Effect of different metal ions on the activity of immobilized and free tannase

\begin{tabular}{|l|c|c|}
\hline \multirow{2}{*}{ Metal ions } & \multicolumn{2}{|c|}{ Relative tannase activity (\%) } \\
\cline { 2 - 3 } & Free tannase & Immobilized tannase \\
\hline $\mathrm{Na}^{+}$ & $53.8 \pm 2.2$ & $66.0 \pm 3.1$ \\
$\mathrm{Hg}^{+2}$ & $13.2 \pm 0.9$ & $22.0 \pm 2.2$ \\
$\mathrm{Cu}^{+2}$ & $52.2 \pm 1.6$ & $68.0 \pm 3.1$ \\
$\mathrm{Fe}^{+2}$ & $52.6 \pm 2.1$ & $61.0 \pm 2.0$ \\
$\mathrm{Zn}^{+2}$ & $72.9 \pm 2.2$ & $85.0 \pm 2.2$ \\
$\mathrm{Ca}^{+2}$ & $112.4 \pm 3.0$ & $118.0 \pm 3.1$ \\
$\mathrm{Mg}^{+2}$ & $96.7 \pm 2.1$ & $107.0 \pm 2.1$ \\
$\mathrm{Mn}^{+2}$ & $69.0 \pm 2.2$ & $71.0 \pm 3.0$ \\
$\mathrm{~K}^{+}$ & $53.2 \pm 1.1$ & $73.0 \pm 1.7$ \\
EDTA & $29.0 \pm 1.2$ & $35.0 \pm 2.1$ \\
Control* & 100 & 100 \\
\hline
\end{tabular}

* Without mineral ions 
Operational Stability of Immobilized Tannase

The operational stability of immobilized tannase is the most important factor affecting the release of gallic acid in tannin bioconversion and in other industrial applications in food, beverage and juices to remove the undesirable effects of tannins such as astringency, bitterness and deterioration of juice quality (CruzAldaco et al., 2009; Srivastava, and Kar, 2010; Belur and Mugeraya, 2011). The operational stability of immobilized tannase is evaluated in repeated batch processes. After each run, the immobilized tannase was washed and reused at optimum conditions for another reaction. The percent of residual tannase activity was determined for 8 cycles. The results in Figure 8 indicate that immobilized tannase retains 84 $\%$ of its original activity after 5 cycles. This is an industrially promising result similar to that obtained by Sharma et al. (2002) and Yu et al. (2007). In addition, $A$. niger tannase immobilized on sodium alginate beads was used repeatedly for 7 cycles with $77 \%$ efficiency (Srivastava and Kar, 2010).

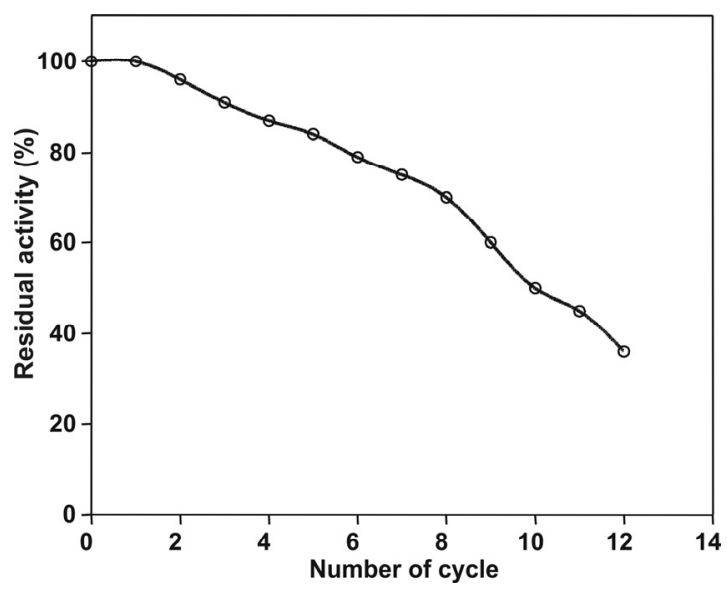

Figure 8: Operational stability of immobilized A. aculeatus tannase

\section{CONCLUSIONS}

In this study, $A$. aculeatus tannase produced by solid sate fermentation on green tea substrate was efficiently immobilized by two methods of entrapment and covalent bonding with cross-linking. Cross-linking within gelatin in the presence of glutaraldehyde gave the highest immobilization yield (28.4\%) compared with the other carriers used. The immobilized tannase remained stable for longer periods of time and also at higher temperatures as compared to the free enzyme. In addition, $\mathrm{pH}$ studies indicated that the enzyme remained significantly active over a broader $\mathrm{pH}$ range (4.5-8.0) compared to the free enzyme in solution. The kinetic properties of tannase revealed a lower affinity of the immobilized enzyme with a higher $\mathrm{K}_{\mathrm{m}}\left(11.8 \mathrm{mg} \mathrm{ml}^{-1}\right)$ compared to free tannase. In addition, after five operational cycles, it was observed that the immobilized tannase retained $84 \%$ of its original activity. The properties of the immobilized tannase described here suggest its value for industrial applications that would not be feasible with the free enzyme system. Further studies are needed of its use in the continuous removal of undesirable tannin molecules in the food and juice industries and in the production of the pharmaceutical antioxidants gallic acid or ellagic acid.

\section{REFERENCES}

Abdel-Naby, M. A., Sherief, A. A., EL-Tanash, A. B., and Mankarios, A. T., Immobilization of Aspergillus oryzae tannase and properties of the immobilized enzyme. Journal of Applied Microbiology, v. 87, 108-114 (1999).

Aguilar, C. N., Rodriguez, R., Gutierrez-Sanchez, G., Augur, C., and Favela-Torres, E., Microbial tannases: Advances and perspectives. Applied Microbiology and Biotechnology, v. 76, 47-59 (2007).

Bajpai, B., and Patil, S., Introduction of tannin acyl hydrolase (EC 3.1.1.20) activity in some members of fungi imperfecti. Enzyme and Microbial Technology, v. 20, 612-614 (1997).

Battestin, V., and Macedo, G. A., Tannase production by Paecilomyces variotii. Bioresource Technology, v. 98, 1832-1837 (2007).

Belmares, R., Contreras-Esquivel, J. C., RodriguezHerrera, R., Coronel, A. R., and Aguilar, C. N., Microbial production of tannase: an enzyme with potential use in food industry. Lebensm.-Wiss. UTechnol., v. 37, 857-864 (2004).

Belur, P. D., and Mugeraya, G., Microbial Production of Tannase: State of the Art. Research Journal of Microbiology, v. 6, (1), 25-40 (2011).

Boadi, D. K., and Neufeld, R. J., Encapsulation of tannase for the hydrolysis of tea tannins. Enzyme and Microbial Technology, v. 28, (7), 590-595 (2001).

Bradford, M., A rapid and sensitive method for the quantitation of microgram quantities of protein utilizing the principle of protein-dye binding. Analytical Biochemistry, v. 72, 248.254 (1976).

Cao, L., Carrier-bound Immobilized Enzymes: Principles, application and design. WILEY-VCH 
Verlag $\mathrm{GmbH}$ and $\mathrm{Co}$. KGaA, Weinheim. ISBN: 3- 527-31232-3 (2005).

Cruz-Aldaco, K., Rivas-Martinez, E., RodriguezHerrera, R., and Aguilar, C. N., Immobilization of Aspergillus niger GH1 Tannase for the Production of the Antioxidant Gallic Acid. International Journal of Engineering and Technology, v. 1, (4), 288-290 (2009).

Deschamps, A. M., Otuk, G., and Lebeault, J. M., Production of tannase and degradation of chestnut tannin by bacteria. Journal of Fermentation Technology, v. 61, 55-59 (1983).

Ghosh, M., and Nanda, G., Thermostability of $\beta$ xylosidase from Aspergillus sydowii MG49. Federation of European Biochemical Societies (FEBS), v. 330, (3), 275-278 (1993).

Gottschalk, N., and Jaenicke, R., Authenticity and reconstitution of immobilized enzymes: characterization and denaturation/renaturation of glucoamylase 11. Biotechnology and Applied Biochemistry, v. 14, 324-335 (1991).

Graminha, E. B. N., Gonçalves, A. Z. L, Pirota, R. D. P. B., Balsalobre, M. A. A., Da-Silva, R., and Gomes, E., Enzyme production by solidstate fermentation: Application to animal nutrition. Animal Feed Science and Technology, v. 144, (1-2), 1-22 (2008).

Hamdy, H. S., Purification and Characterization of a Newly Isolated Stable Long Life Tannase produced by $F$. subglutinans (Wollenweber and Reinking) Nelson et al., Journal of Pharmaceutical Innovation, v. 3, 142-151 (2008).

Hota, S. K., Dutta, J. R., and Banerjee, R., Immobilization of tannase from Rhizopus oryzae and its efficiency to produce gallic acid from tannin rich agro-residues. Indian Journal of Biotechnology, v. 6, 200-204 (2007).

Kennedy, J. F., and Kalogerakis, B., Immobilization of glucoamylase on gelatin by transition-metal chelation. Biochimie, v. 62, (8-9), 549-561 (1980).

Kitano, H., Nakamura, K., and Ise, N., Kinetic studies of enzyme immobilized on anionic polymer lattices. Journal of Applied Biochemistry, v. 4, 34-40 (1982).

Krajewska, B., Leszko, M., and Zaborska, W., Urease immobilized on chitosan membrane: preparation and properties. Journal of Chemical Technology and Biotechnology, v. 48, 337-350 (1990).

Kumar, R., Sharma, J., and Singh, R., Production of tannase from Aspergillus ruber under solid-state fermentation using Jamun (Syzygium cumini) leaves. Microbiological Research, v. 162, (4), 384-390 (2007).
Kumar, R., Kumar, A., Nagpal, R., Sharma, J., and Kumari, A., A novel and sensitive plate assay for screening of tannase-producing bacteria. Annals of Microbiology, v. 60, 177-179 (2010).

Lu, M. J., and Chen, C., Enzymatic tannase treatment of green tea increases in vitro inhibitory activity against N-nitrosation of dimethylamine. Process Biochemistry, v. 42, 1285-1290 (2007).

Lu, M. J., Chu, S. C., Yan, L., and Chen, C., Effect of tannase treatment on protein-tannin aggregation and sensory attributes of green tea infusion. Food Science and Technology, v. 42, 338-342 (2009).

Murugan, K., and Al-Sohaibani, S. A., Biocompatibale tannin and associated color from tannery effluent using the biomass and tannin acyl hydrolase (E.C.3.1.1.20) enzymes of mango industry solid waste isolate Aspergillus candidus MTCC 9628. Research Journal of Microbiology, v. 5, 262-271 (2010).

Nishira, H., and Mugibayashi, N., Tannin decomposing enzymes of molds: 1-determination of the enzyme activity and tannin decomposing activity of the selected mold. Science Reports, Hyogo University, Agricultural Series. Agricultural Chemistry, v. 1, 6-10 (1958).

Rout, S., and Banerjee, R., Production of tannase under $\mathrm{mSSF}$ and its application in fruit juice debittering. Indian Journal of Biotechnology, v. 5, 346-350 (2006).

Sharma, S., Bhat, T. K., and Gupta, M. N., Bioaffinity immobilization of tannase from Aspergillus niger on concanavalin A-Sepharose CL- 4B. Biotechnology and Applied Biochemistry, v. 35, (3), 165-169 (2002).

Sharma, S., Agarwal, L., and Kumar, R., Purification, immobilization and characterization of tannase from Penicillium variable. Bioresource Technology, v. 99, 2544-2551 (2008).

Sherief, A. A., EL-Tanash A. B., and Alshaymaa Nour, Optimization of tannase biosynthesis from two local Aspergilli using commercial green tea as solid substrate. Biotechnology, v. 10, (1), 7885 (2011).

Srivastava, A., and Kar, R., Application of immobilized tannase from Aspergillus niger for the removal of tannin from myrobalan juice. Indian Journal of Microbiology, v. 50, (1), 46-51 (2010).

Su, E., Xia, T., Gao, L., Dai, Q., and Zhang, Z., Immobilization and Characterization of Tannase and its Haze-removing. Food Science and Technology International, v. 15, 545-552 (2010). 
Vallee, B. L., and Ulmer, D. D., Biochemical effects of mercury, cadmiun, and lead. Annual Review of Biochemistry, 41, 91-128 (1972).

Van de Lagemaat, J., and Pyle, D. L., Tannase In: Enzyme Technology, Pandey A., Webb C., Soccol C. R., Larroche C., (Eds.). 1st Edn, Springer, New York, pp. 380-397 (2006).

Vaquero, I., Marcobal, A., and Munoz, R., Tannase activity by lactic acid bacteria isolated from grape must and wine. International Journal of Food Microbiology, v. 96, 199-204 (2004).

$\mathrm{Yu}, \mathrm{X}$., and Li, Y., Kinetics and thermodynamics of synthesis of propyl gallate by mycelium-bound tannase from Aspergillus niger in organic solvent. Journal of Molecular Catalysis B: Enzymatic, v. 40, 44-50 (2006).
Yu, X., Li, Y., Wang, C., and Wang, D., Immobilization of Aspergillus niger tannase by micro encapsulation and its kinetic characterization. Biotechnology and Applied Biochemistry, v. 40, 151-155 (2004).

Yu, X., Li, Y., Zhou, S., and Zheng, Y., Synthesis of propyl gallate by mycelium-bound tannase from Aspergillus niger in organic solvent. World Journal of Microbiology and Biotechnology, v. 23, 1091-1098 (2007).

Zhong, X., Peng, L., Zheng, S., Sun, Z., Ren, Y., Dong, M., and $\mathrm{Xu}, \mathrm{A}$., Secretion, purification and characterization of a recombinant Aspergillus oryzae tannase in Pichia pastoris. Protein Expression and Purification, v. 36, 165-169 (2004). 